\author{
Aleksy Kucy \\ (iD https://orcid.org/0000-0001-6655-6886 \\ Uniwersytet Łódzki \\ Wydziat Filologiczny \\ Instytut Rusycystyki \\ Zaktad Językoznawstwa \\ 90-226 Łódź \\ ul. Pomorska 171/173 \\ aleksy.kucy@uni.lodz.pl
}

\title{
Polisemantyczność przekazu biblijnego Słowo Boże w wymiarze czasowo-przestrzennym
}

\author{
The Polysemantic Nature of the Biblical Message \\ The Word of God in the Temporal and Spatial Dimension \\ Полисемантичность библейского посыла \\ Слово Божье во временном и пространственном измерении
}

\begin{abstract}
Streszczenie
Współczesna interpretacja Pisma Świętego powinna uwzględniać, oprócz wymiaru kontekstualnego i historycznego, także wymiary ukrytej symboliki sakralnej. Bazując na własnym doświadczeniu lingwistycznym i religioznawczym zaproponowaliśmy trójkierunkowy model interpretacyjny przekazu biblijnego. Na podstawie zaproponowanych rozwiązań egzegetycznych przeprowadziliśmy analizę prawidłowości zastosowanego modelu w oparciu o dwa pojęcia biblijne, jakimi są Obraz Boży oraz Najświętsza Maria Panna.
\end{abstract}

Słowa kluczowe: Biblia, interpretacja, kierunki semantyczne, egzegeza, modele interpretacyjne.

\section{Summary}

Contemporary interpretation of the Scriptures should not ignore, besides the contextual and historical dimension, the aspect of discreet sacred symbolism. Based on our linguistic and religious knowledge, we proposed a three-layered model of interpretation of the biblical content. Given the proposed exegetic solutions, we validated the applied model against two biblical concepts, namely God's Image and the Blessed Virgin Mary.

Keywords: Bible, interpretation, semantic trends, exegesis, interpretation models. 


\section{Резюме}

Современная интерпретация Священного Писания должна учитывать не только контекстуальное и историческое измерение, но и перспективу скрытого сакрального символизма. Основываясь на нашем собственном лингвистическом и религиозном опыте, мы предложили трехстороннюю модель интерпретации библейского послания. На основе предложенных экзегетических решений мы провели анализ правильности используемой модели, основанный на двух библейских понятиях, а именно: «Образ Божий» и «Пресвятая Дева Мария».

Ключевые слова: Библия, толкование, семантические направления, экзегеза, интерпретационные модели.

Pismo Święte nie jest stricte tworem ludzkim, bo choć ludzka ręka zapisywała na kartce papieru słowa i zdania, to zostały one natchnione i zainspirowane przez Ducha Świętego. To jest główny aksjomat wiary, który należy przyjąć przed rozważaniem na temat treści tekstu sakralnego. Jednak, co on oznacza w sensie praktycznym? Z kolei, czy źródło przesłania werbalnego ma znaczenie we właściwym odbiorze jego pochodzenia i czy umysł ludzki jest w stanie samodzielnie prawidłowo odczytywać prawidłowe znaczenia przekazu biblijnego? Powyższe pytania wydają się być retoryczne, lecz próba zastanowienia się i znalezienia na nie odpowiedzi pokazuje, że nie są to sprawy bagatelne.

Współczesny świat obfituje w wiele denominacji i ruchów usiłujących na własny sposób i w oparciu o wyłącznie własny potencjał intelektualny „rozkodowywać" oraz zinterpretować przekaz biblijny bądź to w przypadku historycznej wykładni opisywanych w Piśmie Świętym zjawisk, bądź nauki moralnej i przekazu soteriologicznego w nim zawartego. Nierzadko w czasach najnowszych można spotkać osobę lub osoby, traktujące przekaz Biblii w sposób instrumentalny, wykorzystując poszczególne zdania bądź całe fragmenty do uzasadniania własnych poglądów lub do podważenia czyichś.

Owszem, rzeczą normalną jest krytyczne ocenianie informacji, które do nas docierają, lecz w odniesieniu do Pisma Świętego niebezpieczeństwo polega na tym, że chodzi o nic innego jak o zbawienie duszy i sprawę życia wiecznego. Na poziomie jednostki brak właściwego rozumienia przesłania biblijnego prowadzi do tego, że osoba, której wydaje się, iż kroczy właściwą drogą, może stać w miejscu lub co gorsza, znajdować się w duchowym impasie. $Z$ kolei na poziomie społeczności zbiorowej ów brak może stać się przyczyną rozłamu i powstania jeszcze większego duchowego impasu ${ }^{1}$.

${ }^{1}$ Większość podziałów denominacyjnych na świecie wynika z różnic interpretacyjnych i soteriologicznych poszczególnych konceptów biblijnych. Każde chrześcijańskie wyznanie aspiruje do większej lub mniejszej wyłączności egzegetycznej, broniąc swoich racji w oparciu o zaproponowane modele interpretacyjne. 
W odniesieniu do przekazu biblijnego na wstępie należy wprowadzić bardzo ważną kategoryzację. Otóż podstawowym błędem poznawczym, popełnianym przez duchowych nowicjuszy lub interpretatorów Pisma Świętego, jest niezrozumienie substancjalnego rozgraniczenia podmiotowości bytów stworzonych i Bytu Niestworzonego ${ }^{2}$. Głównym paradygmatem poznawczym w traktowaniu Boga jest to, że w stosunku do całego swojego stworzenia widzialnego i niewidzialnego jest On czymś zupełnie innym, nie przeciwstawnym i nie przeciwległym, tylko innym substancjalnie i egzystencjalnie - jest Bytem niestworzonym, kardynalnie oraz zdecydowanie różniącym się od bytów stworzonych. Warto przy tym zaznaczyć, że tu kryje się stała pułapka poznawcza, która dotyczy każdego dociekliwego badacza, przystępującego do zgłębiania tajemnic sakralnych. Bardzo upraszczając sprawę, można ją ująć w następujący sposób. Wyobraźmy sobie, że chcemy zdefiniować pojęcie stolu. Mówimy lub pytamy: „czym jest stól’? Zazwyczaj może paść kilka definicji w różny sposób zbliżonych bądź oddalonych od siebie, bowiem każdy człowiek ma własne wyobrażenie o przedmiocie dociekań. Jedna osoba skojarzy stół z kształtem koła na kolumnowej nodze o czterech podnóżach, druga - z kwadratem bądź prostokątem z czterema nogami i tak dalej: wszystko zależy od wcześniejszego doświadczenia i posiadanej wiedzy konkretnej osoby. Niemniej u podstaw każdego definiowania leży myślenie logiczne i to ono stanowi tę pułapkę. Chcąc myśleć lub rozważać o Bogu, świadomość ludzka włącza ten właśnie tryb myślenia, myślenia logicznego, ignorując fakt substancjalnego rozgraniczenia i hermetyczności poznawczej bytu stworzonego w stosunku do Bytu niestworzonego. Nie można na tej podstawie wyciągnąć wniosku o niemożności jakiegokolwiek poznania Boga przez Jego stworzenie, przez człowieka. Niemniej należy stwierdzić jego kategoryczne ograniczenie, zwłaszcza w materii istoty czy też natury Stwórcy (Иоанн Дамаскин, 1910, 140).

W omawianym kontekście Pismo Święte stanowi klasyczny przykład specyfiki poznawczej, w tym także interpretacji przekazu informacyjnego w nim zawartego. Ważnym postulatem przy tej okazji jest stwierdzenie, że Biblia stanowi ten rodzaj przesłania, które stwarza określone możliwości poznawcze mimo wspomnianej granicy rozdzielającej. Z kolei czynnikiem wymaganym do prawidłowego przebiegu owego poznania jest udział samego Stwórcy w tym procesie. Nie przypadkowo, Ojcowie Kościoła traktują Pismo Święte właśnie jako Objawienie (Блаженный Феофилакт, 2010, 60), poprzez które niestworzony Bóg próbuje przekazać określone treści informacyjne bytu stworzonemu. Skoro zaś ten przekaz pochodzi od konkretnego Źródła, to również jego odbiór i właściwa interpretacja winna przebiegać zgodnie z intencją i zamysłem owego Źródła. Innymi słowy, w komunikacji Boga ze swoim stworzeniem to drugie powinno rozumieć

2 Św. Maksym Wyznawca w sposób szczególny dał teologiczne uzasadnienie potrzeby rozgraniczenia tych dwóch zagadnień, mianowicie różnicy pomiędzy naturą ludzką stworzoną a Boską niestworzoną (zob.: Преподобный Максим Исповедник, 2006, 18-19). 
kierowane do niej przesłanie zgodnie z zamiarem wysyłającego, co z kolei zadaniem łatwym nie jest.

Powinniśmy przyznać jeszcze raz, że choć tekst przekazu biblijnego był napisany ludzką ręką, to działo się to wyłącznie poprzez inspirację teistyczną. Biorąc pod uwagę ograniczenia poznawcze w postaci logicznego myślenia, zmuszeni jesteśmy do zastosowania odmiennego mechanizmu interpretacyjnego, zakładającego $\mathrm{z}$ jednej strony uniwersalizm przekazu biblijnego, jego ponadczasowy charakter, a z drugiej - jego semantyczną wielokierunkowość i wielopłaszczyznowość.

Tak zarysowana istota przesłania Bożego wydaje się być jedynym racjonalnym uzasadnieniem występowania tak dużej liczby stanowisk interpretacyjnych i punktów odniesienia. $Z$ tym, że nie należy oczywiście zapominać o słuszności bądź prawidłowości poznawczej, bowiem wielopłaszczyznowość nie oznacza sprzeczności, i na odwrót. Stąd występowanie różnych kategoryzacji i komentarzy w stosunku do konkretnych wątków biblijnych nie powinno wprowadzać zamieszania pojęciowego, lecz motywować do wyodrębnienia właściwej ścieżki znaczeniowej. Właściwa egzegeza Pisma Świętego nie może być wewnętrznie sprzeczna, lecz powinna zawierać treści uzupełniające się i związane z głównym wątkiem przesłania. Dlatego też można mówić tylko o jednym nurcie egzegetycznym, wewnętrznie spójnym i dającym możliwość odbierania wszystkich treści przekazu biblijnego zgodnie z zamysłem jego Intencjodawcy (Лосский, 2006, 322).

Zatem analizując słowo Boże w wymiarze czasowo-przestrzennym możemy wyodrębnić trzykierunkowy model interpretacyjny lub poznawczy, w ramach którego można rozpatrywać owe konkretne wątki. Określmy je jako a) uniwersalny, wynikający z racjonalności myślenia oraz kolei rzeczy, b) symboliczny ujawnio$n y$, związany z czasoprzestrzenią i warunkami historycznymi oraz c) symboliczny ukryty, zakładający występowanie treści zakodowanych, służących do sygnalizowania wydarzeń, które mają dopiero nadejść w przyszłości³. Kierunek uniwersalny, choć jest bardzo konkretny i namierzalny, dający się z łatwością zinterpretować w kwestii identyfikacji przedmiotowej, to odgrywa mniejsze znaczenia w stosunku do dwóch ostatnich. Kierunek symboliczny ujawniony z kolei to taki, który zakłada występowanie „drugiego” dna znaczeniowego, mającego wpływ na motywację i podejmowanie działań w aktualnej przestrzeni historycznej. Z kolei kierunek symboliczny ukryty stanowi taki rodzaj semantyki, która odwołuje się do zamysłu przyszłościowego Stwórcy i poprzez użyte symbole przekazuje z jednej strony Jego intencje, $\mathrm{z}$ drugiej zaś odkrywa w zakodowanej perspektywie plany historyczne i rzeczowe mające nadejść nawet w bardzo dalekiej przyszłości.

Rysą charakterystyczną całego przekazu jest krzyżowanie się w tekście biblijnym treści w tych trzech kierunkach znaczeniowych w odniesieniu do kon-

${ }^{3}$ Kategoria czasu także znajduje się „poza” Bytem niestworzonym: Bóg jako Stwórca czasu jest jednocześnie poza nim, stąd przyszłość kategorii czasoprzestrzeni dotyczy tylko bytu stworzonego. (zob.: Św. Augustyn, 1994, 264-266). 
kretnych przedmiotów, a także występowanie wątków autonomicznych w jednym lub kilku z nich. Należy tu zaznaczyć, że powyższe zjawisko obejmuje w większym stopniu przedmioty służące w przestrzeni historycznej jako symbole, aniżeli pojęcia i kategorie teologiczne jako że ostatnie stanowią przedmiot jeszcze bardziej zaawansowanej interpretacji. Dla tego rodzaju określeń można mówić o występowaniu wartości dodanej, czy też dodatkowej perspektywy transcendentnej. Ponadto, zjawisko polisemantyczności m.in. nie obejmuje nazewnictwa atrybutywnego.

Przejdźmy jednak do konkretnych przykładów ilustrujących złożoność, a z drugiej strony prostotę omawianego zjawiska. Proponuję rozważyć kategorię obrazu Bożego jako tę bardziej rozbudowaną semantycznie, posiadającą dodatkową perspektywę teologiczną i następnie przejść do symboliki przedmiotowej, wziąwszy jako przykład kategorię Góry Syjon.

W odniesieniu do pojęcia obrazu Bożego myśl patrystyczna wczesnego chrześcijaństwa bardzo ostrożnie traktuje tę kwestię, ukazując raczej duchowe składniki, które można odnieść do kategorii obrazu i podobieństwa oraz często unikając - z nielicznymi wyjątkami - formalnego definiowania tego pojęcia. Niemniej pojęcie to w myśli patrystycznej ma bardzo bogatą tradycję i rozbudowaną semantykę. W interpretacji egzegetycznej możemy znaleźć zarówno szerokie traktowanie tego pojęcia, jak i bardzo wąskie, przedmiotowe. Tak, określenie $n a$ obraz u Ojców Kościoła w jednym przypadku charakteryzowało posiadanie przez człowieka wolnej woli, w drugim wyrażało jego zdolność do refleksji i potrzebę samostanowienia, w innym przypadku świadczyło o relacjach duszy i ciała, jeszcze $\mathrm{w}$ innym kojarzone było $\mathrm{z}$ intelektem, niekiedy również stanowiło rozgraniczenie pomiędzy naturą a osobowością. Ponadto, w obrębie samego pojęcia obrazu można mówić o obrazie jako takim, jak też o tym, jakie cechy tego obrazu możemy znaleźć w człowieku, który stworzony na obraz stricte obrazem tym przecież nie jest.

Pismo Święte w tym kontekście stanowi pozycję wyjściową, zwłaszcza w określeniu obrazu jako takiego. Bezpośrednie wskazanie podmiotowego adresata tej kategorii znajdujemy u Św. Pawła. Apostoł narodów mówiąc o Chrystusie w kontekście soteriologicznym nazywa Go obrazem Boga niewidzialnego:

On jest [mowa o Chrystusie] obrazem Boga niewidzialnego - Pierworodnym wobec każdego stworzenia, bo w Nim zostało wszystko stworzone: i to, co w niebiosach, i to, co na ziemi, byty widzialne i niewidzialne, czy Trony, czy Panowania, czy Zwierzchności, czy Władze. Wszystko przez Niego i dla Niego zostało stworzone. On jest przed wszystkim i wszystko w Nim ma istnienie. I On jest Głową Ciała - Kościoła. On jest Początkiem, Pierworodnym spośród umarłych (Kol 1:12-18).

Panayiotis Nellas, współczesny grecki teolog, odbiera powyższe treści nie tyle w kategoriach teologicznych, co antropologicznych i kosmologicznych. Zawarty w nim został jego zdaniem stosunek Chrystusa wobec człowieka i wszech- 
świata. Dalsze zagłębienie się w tej analizie pokazuje, że taki był właśnie tok myślenia Apostoła, nawiązujący do autorów Starego i Nowego Testamentu, następnie odzwierciedlony w interpretacjach Ojców Kościoła, mianowicie postulujący naukę o Chrystusie jako obrazie Bożym, zaś o człowieku - jako o obrazie Obrazu (Неллас, 2011, 19).

Przy czym, gdy mowa jest o Obrazie, chodzi nie tyle o sam Logos jako taki, co o Logos Wcielony. Obrazem, na który został stworzony człowiek, od początku był Chrystus, w tym znaczeniu, że to jedyny prawdziwy antropologiczny telos: połączenie niepołączalnych natur - Bożej i ludzkiej - w jednej osobie. Na tej podstawie możemy wyciągnąć też inny wniosek, mianowicie taki, że aktu Wcielenia nie należy rozpatrywać wyłącznie w kontekście ekonomii Bożego działania na rzecz zbawienia upadłej natury (por.: Szczerba, 2008, 92). Inaczej należało by uznać, iż wróg rodzaju ludzkiego ma wpływ na decyzje i działania Boże, co jest oczywiście niemożliwe. Dlatego też Chrystus od początku był $O b$ razem, na wzór którego stworzony był Adam (por.: Wyrąbkiewicz, 2014, 127). To, co uzyskał Adam w akcie stworzenia na obraz, to możliwość obcowania z Bogiem poprzez Jego niestworzone Energie, które powinny były prowadzić naturę człowieka do hipostazyjnej jedności z Bożym Logosem w Chrystusie. Ten cel od początku był stawiany Adamowi i nie został zmieniony nawet po upadku.

Jeśli w kontekście antropologicznej nauki w taki właśnie sposób odpowiemy na pytanie odnośnie obrazu Bożego, to stanie się zrozumiała nie tylko wewnętrzna treść tego pojęcia, ale i wartość dodana, mianowicie znaczenie określenia podobieństwo. Większość komentatorów biblijnych zgadza się co do podstawowej różnicy w rozróżnieniu pomiędzy obrazem a podobieństwem, która sprowadza się do przysłowiowej statyczności pierwszego a dynamizmu drugiego. Jeśli obraz jest czymś określonym, to podobieństwo stanowi raczej proces dynamiczny, polegający na przyswajaniu, wrastaniu w ów obraz. Georgios Mantzaridis opisuje to w sposób następujący:

Słowo podobieństwo, w znaczeniu użytym w Septuagincie, wyraża coś dynamicznego i jeszcze nie zrealizowanego, natomiast słowo obraz oznacza stan zrealizowany, co w naszym kontekście stanowi punkt wyjścia na drodze zdobywania podobieństwa. [...] To, co jest na obraz stanowi powszechną własność wszystkich ludzi, natomiast to, co jest na podobieństwo jest czymś tylko potencjalnym. [...] Podobieństwo do Boga, chociaż stanowi cel istnienia człowie$\mathrm{ka}$, to jednak nie zostało mu narzucone, lecz pozostawione jego wolnej woli. Dzięki wolnemu poddaniu się woli Boga i stałemu prowadzeniu przez Jego łaskę, człowiek może udoskonalać i rozwijać dar obrazu, czyniąc go własnością indywidualną, pewną i dynamiczną, a przez to stawać się podobnym Bogu" (Mantzaridis, 1997, 24-25).

W ten sposób znaczenie powyższego symbolu ukrytego ujawnia się w czasoprzestrzeni oraz w samym Piśmie Świętym, odkrywając jego atrybutywne cechy i sygnalizując podmiotowego adresata. 
Kolejne pojęcie do analizy to Góra Syjon. Ta wspaniała kategoria stanowi dobry przykład trzykierunkowego modelu semantycznego, gdzie każdy z kierunków może być rozpatrywany osobno, jak i w harmonijnej symbiozie z pozostałymi. Kierunek uniwersalny ukazuje nam historyczno-geograficzną stronę tego zjawiska. Góra czy też wzgórze Syjon znajdujące się w południowo-wschodniej części Jerozolimy, zostało zdobyte przez króla Dawida. Przed zawładnięciem wzgórza przez Dawida Syjon znajdował się w rękach Jebuzytów, którzy zbudowali tam twierdzę. Po jej zdobyciu Syjon dostał kolejną nazwę - Ir-Dawid, co oznaczało Gród Dawida (Православная энииклопедия, 2006, 547). Znajdowały się tam grobowce króla Dawida oraz pozostałych królów judejskich (Архим. Никифор, 1891, 160-161). Salomon z kolei na wzgórzu Syjon wzniósł pałac królewski i Świątynię. Od tego czasu miano Syjonu otrzymało całe wzgórze, a później zaczęto tak nazywać samą Jerozolimę (Архим. Никифор, 1891, 160-161).

Biblia 163 razy odwołuje się do tego pojęcia ${ }^{4}$. Charakterystyczną cechą tego odwołania jest dominacja kierunku symbolicznego ujawnionego, gdzie główne pole semantyczne sprowadza się do wymiaru sakralnego, do Bożego wyboru tego wybornego wzgórza jako oznaki unii człowieka z Bogiem. W tym ujęciu Syjon w Biblii występuje w kilku znaczeniach: jako „gród Dawida”, „góra święta”, „dom Boży”, „królewskie miasto Boże”. Dla Hebrajczyków to drugie dno oznaczało całą Jerozolimę, całą Judeę oraz naród Judejski. Z kolei Prorocy używali tego pojęcia jako synonimu Królestwa Bożego w jego pełni, na niebie i na ziemi, które powinno trwać aż do spełnienia się wszystkich proroctw i nadejścia nowej ery (Толковая Библия, 2009, 31-32). Z kolei w znaczeniu przenośnym Syjon jawi się jako miejsce zamieszkania Boga w niebie, jako miejsce najwyższego objawienia Jego chwały. Stąd nadchodzi zbawienie dla Izraela i sąd dla pogan:

- Śpiewajcie Panu, co mieszka na Syjonie, pośród narodów głoście Jego dzieła, bo mściciel krwi pamięta o ubogich, pamięta, a nie zapomina ich wołania.

- Kto przyniesie z Syjonu zbawienie Izraelowi? Gdy Bóg odmieni los swego narodu, Jakub się uraduje, Izrael się ucieszy (Ps 53:7).

Tam też przyjdą odkupieni przez Pana:

- Ten, kto pozostał żywy na Syjonie, i który się ostał w Jeruzalem, każdy będzie nazwany świętym i wpisany do [Księgi] Życia w Jeruzalem.

- Wtedy Pan przyjdzie [spocząć] na całej przestrzeni góry Syjonu i na tych, którzy się tam zgromadzą, we dnie jak obłok z dymu, w nocy jako olśniewający płomień ognia (Iz 4:5).

Wreszcie kierunek symbolu ujawnionego w przypadku Góry Syjon płynnie przechodzi i splata się z kierunkiem symbolicznym ukrytym. Psalm 68, werset 16 to ukazuje w sposób szczególny:

\footnotetext{
${ }^{4}$ Wyliczono na podstawie statystyk elektronicznych.
} 
Góra Boża, Góra thusta: góra obfita, góra tłusta. Co się przypatrujecie górom zsiadłym? Góra, na której Bogu podoba się mieszkać; albowiem Pan będzie mieszkał na wieki. Wóz Boży, dziesiątki tysięcy rozmaity, tysiące weselących się: Pan między nimi na Synai, w świątnicy (Ps 68:16-18).

Ujawnienie ukrytej semantyki w perspektywie historycznej, co też objawia się pełną zgodnością w wykładni Ojców Kościoła, objawia nam to znaczenie jako Dziewicę Marię, mającą urodzić Chrystusa - Wcielonego Syna Bożego.

Wołajcie góry - mówi św. Jan Damasceński - istoty rozumne, dążące do wysokości duchowej kontemplacji: rodzi się przewspaniała góra Pańska, swoją wysokością i miejscem przewyższająca wszelkie wzgórze, i każdą górę - wielkość aniołów i ludzi... najświętszy szczyt Synaju, który pokrywa nie mrok, nie burza, nie przerażający ogień, lecz światła światłość Ducha Świętego (Дамаскин, 1997, 254) 5

Synonimizacja tego samego pojęcia następuje zwłaszcza w psalmie 87:

Budowla Jego jest na świętych górach: Pan miłuje bramy Syjonu bardziej niż wszystkie namioty Jakuba. Wspaniałe rzeczy głoszą o tobie, o miasto Boże! Wymienię Rahab i Babel wśród tych, co mnie znają; oto Filistyni i Tyr razem z Kusz [powiedzą]: „Ten [i ten] się tam urodził”. O Syjonie zaś będzie się mówić: „Oto ten w nim się narodził, a Najwyższy sam go umacnia”. Pan spisując wylicza narody: „Ten się tam urodził” (Ps 87:3-5).

W swojej świętości i chwale, w świetle jednolitej i spójnej interpretacji patrystycznej, Dziewica Maria to trzon konotacyjnych skojarzeń znaczeniowych. Stąd w Piśmie Świętym Ona jest grodem Wszech Boga, ottarzem i tronem, wzgórzem wybranym itp. Tu nie tylko ma miejsce krzyżowanie się perspektyw semantycznych, ale też dochodzi do wywołania lawiny znaczeniowej, kiedy to jeden po drugim powstają nowe wątki i odniesienia przedmiotowe. Okazuje się bowiem, że w odniesieniu do Marii Panny tekst biblijny ma zbyt wiele aluzji, by mówić o jakiejś przypadkowości: „Góra”, „Brama przez którą wchodzi Król”, „Tron”, „Ołtarz”, „Arka Przymierza”, „Krzew Gorejący”, „Królowa w złocie z Ofiru”, wreszcie „Panna”. Wszystkie powyższe nominacje możemy rozpatrywać w każdej z trzech perspektyw, lecz ta trzecia wydaje się tu być najważniejszą:

Kimże jest ta, która świeci z wysoka jak zorza, piękna jak księżyc, jaśniejąca jak słońce, groźna jak zbrojne zastępy? - pyta Salomon (Pnp 6:10).

Uwzględnienie powyższej pełni semantycznej bazującej na zaproponowanym przez nas trójkierunkowym modelu interpretacyjnym wydaje się być ważnym składnikiem poznawczym, mogącym uchronić współczesnych badaczy przekazu biblijnego przed złem materialnym. Faktem jest, że większość podziałów denominacyjnych wewnątrz chrześcijaństwa jest spowodowana bądź konstruowana

\footnotetext{
5 Tłumaczenie autora tekstu.
} 
właśnie w oparciu o interpretację przekazu biblijnego. Zazwyczaj, gdy dochodzi do krytyki myśli patrystycznej, to mamy do czynienia wyłącznie z literalizmem oraz pomijaniem obecności symbolizmu ujawnionego i ukrytego, ignorowanie którego skutkuje niewłaściwym odbiorem konkretnego przesłania, a co za tym idzie, błędną interpretacją zakodowanych elementów tekstowych.

\section{BIBLIOGRAFIA}

Bogacz, R. (2013). Cuda w Starym Testamencie. Kraków: Wydawnictwo M.

Czerski, J. (2012). Metodologia Nowego Testamentu. Opole: Redakcja Wydawnictw Wydziału Teologicznego Uniwersytetu Opolskiego.

Dogondke, D. (2013). Charakter deuteronomistyczny Księgi Malachiasza. Teologiczne implikacje intertekstualnej analizy biblijnej. Warszawa: Lingua Sacra.

Jelonek, T., Bogacz R. (red.). (2012). Biblia w kulturze świata. Aspekty biblijnego przestania. Kraków: Wydawnictwo Naukowe UPJPII.

Korzec, C. (2013). Ścieżka biblijnego konsensusu: ku integralnej teologii biblijnej. Wrocław: Bibliotheca Biblica.

Kręcidło, J. (2013). Honor $i$ wstyd w interpretacji Ewangelii. Szkice z egzegezy antropologiczno- kulturowej. Warszawa: VERBINUM.

McDowell, J. (1979). Evidence That Demands A Verdict. California: Thomas Nelson Inc.

Muszytowska, D. (2011). Lektyka Salomona. Biblia-symbol-interpretacja. Warszawa.

Rittel, S. (2013). Obrazy ziemi w Biblii. Systemowe interpretacje realioznawcze. Kielce: Oficyna Wydawnicza „Marka”.

Szymik, S. (red.) (2013). Biblia kodem kulturowym Europy. Lublin: Katolicki Uniwersytet Lubelski Jana Pawła II.

Архим. Никифор (ред.). (1891). Библейская энииклопедия. Москва: Типография А.И. Спегиревой.

Блаженный Феофилакт Болгарский. (2010). Толкование блаженного Феофилакта Болгарского на святое Евангелие. Москва: Летопись.

Лосский, В. (2006). Боговидение. Москва: Издательство Свято-Владимирского Братства.

Лопухин, А. (1904-1913). Толковая Библия или комментарии на все книги Св. писания Ветхого и Нового Завета. Санкт-Петербург: Синодальная Типография.

Преподобные Варсонуфий и Иоанн. (1852). Руководство к духовной жизни. Москва: Университетская Типография.

Преподобный Иоанн Кассиан Римлянин. (2000). Писания. Москва: АСТ.

Протоиерей Александр Мень. (1997). Сын Человеческий. Москва: ВИТА.

Святитель Василий Великий. (2014). Беседы на псалмы. Москва: Сибирская Благозвонница.

Святитель Игнатий Брянчанинов. (2009). Аскетические оnыmbl, t. 1. Минск: Лучи Софии

Святитель Иоанн Златоуст. (1906). Беседы на книгу Бытия. Санкт-Петербург: Санкт-Петербургская Духовная Академия.

$* * *$

Arkhim. Nikifor (red.). (1891). Bibleiskaya entsiklopediya. Moscow: Tipografiya A.I. Spegirevoi. Blazhennyi Feofilakt Bolgarskii. (2010). Tolkovanie blazhennogo Feofilakta Bolgarskogo na svyatoe Evangelie. Moscow: Letopis'. 
Lopukhin, A. (1904-1913). Tolkovaya Bibliya ili kommentarii na vse knigi Sv. pisaniya Vetkhogo i Novogo Zaveta. St. Petersburg: Sinodal'naya Tipografiya.

Losskii, V. (2006). Bogovidenie. Moscow: Izdatel'stvo Svyato-Vladimirskogo Bratstva.

Prepodobnye Varsonufii i Ioann. (1852). Rukovodstvo $k$ dukhovnoi zhizni. Moscow: Universitetskaya Tipografiya.

Prepodobnyi Ioann Kassian Rimlyanin. (2000). Pisaniya. Moscow: AST.

Protoierei Aleksandr Men'. (1997). Syn Chelovecheskii. Moscow: VITA.

Svyatitel' Ignatii Bryanchaninov. (2009). Asketicheskie opyty, t. 1. Minsk: Luchi Sofii.

Svyatitel' Ioann Zlatoust. (1906). Besedy na knigu Bytiya. St. Petersburg: Sankt-Peterburgskaya Dukhovnaya Akademiya.

Svyatitel' Vasilii Velikii. (2014). Besedy na psalmy. Moscow: Sibirskaya Blagozvonnitsa. 